\title{
Update on Recent Activities at the Arkansas Archeological Survey's Henderson State University Research Station in Arkadelphia
}

Mary Beth D. Trubitt

Arkansas Archeological Survey, HSU Research Station

Follow this and additional works at: https://scholarworks.sfasu.edu/ita

Part of the American Material Culture Commons, Archaeological Anthropology Commons, Environmental Studies Commons, Other American Studies Commons, Other Arts and Humanities Commons, Other History of Art, Architecture, and Archaeology Commons, and the United States History Commons

Tell us how this article helped you.

This Article is brought to you for free and open access by the Center for Regional Heritage Research at SFA ScholarWorks. It has been accepted for inclusion in Index of Texas Archaeology: Open Access Gray Literature from the Lone Star State by an authorized editor of SFA ScholarWorks. For more information, please contact cdsscholarworks@sfasu.edu. 


\section{Update on Recent Activities at the Arkansas Archeological Survey's Henderson State University Research Station in Arkadelphia}

\section{Creative Commons License}

(c) (i) (8)

This work is licensed under a Creative Commons Attribution-NonCommercial 4.0 International License 


\title{
Current Research:
}

\section{Update on Recent Activities at the Arkansas Archeological Survey's Henderson State University Research Station in Arkadelphia}

\author{
Mary Beth Trubitt
}

Arkansas Archeological Survey, Henderson State University Research Station

The Arkansas Archeological Survey's Henderson State University Research Station (ARAS/HSU) has been active with several small field projects this year, as well as on-going work in the lab. In February and March 2016, Mary Beth Trubitt and Katie Leslie advised Hot Springs National Park personnel on placement of four soil moisture monitors so as to avoid cultural features at 3GA22, a significant novaculite quarry with prehistoric and historic components (Holmes 1891, 1919; Trubitt 2005). In the process, we were able to map additional quarry features, most of which are associated with early twentieth century whetstone procurement (Figure 1). Our fieldwork and documentation resulted in extending the site boundaries. Eight shovel tests were excavated during the park's installation of soil monitoring equipment (Figure 2). This represents the first subsurface archeological testing at this quarry. The novaculite debris from shovel tests included quarry waste and natural talus, but few flakes and no tools or diagnostic artifacts were found. After analysis of lithic debris, a report was prepared that outlines past research on the site and its significance, and summarizes the results of the project (AMASDA 6994) (Trubitt 2016).

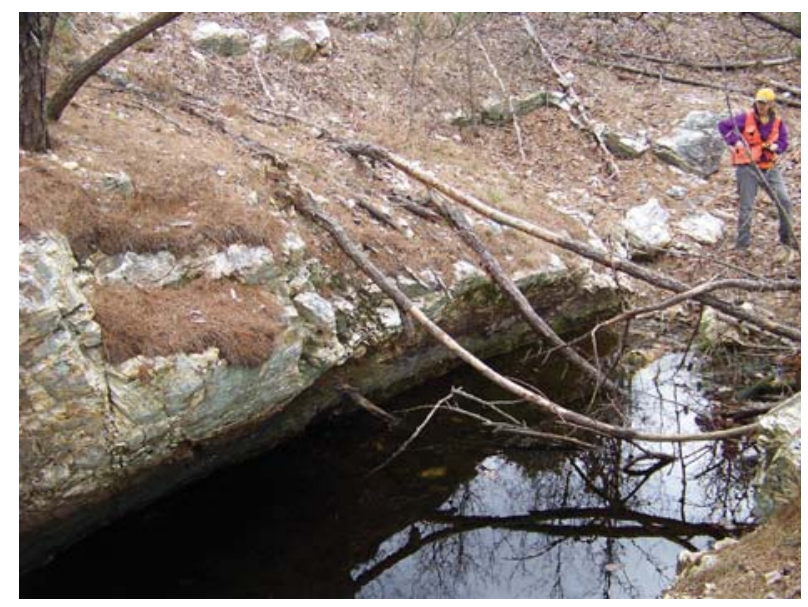

Figure 1. Large water-filled quarry trench at 3GA22 (Mary Beth Trubitt in background, Arkansas Archeological Survey).

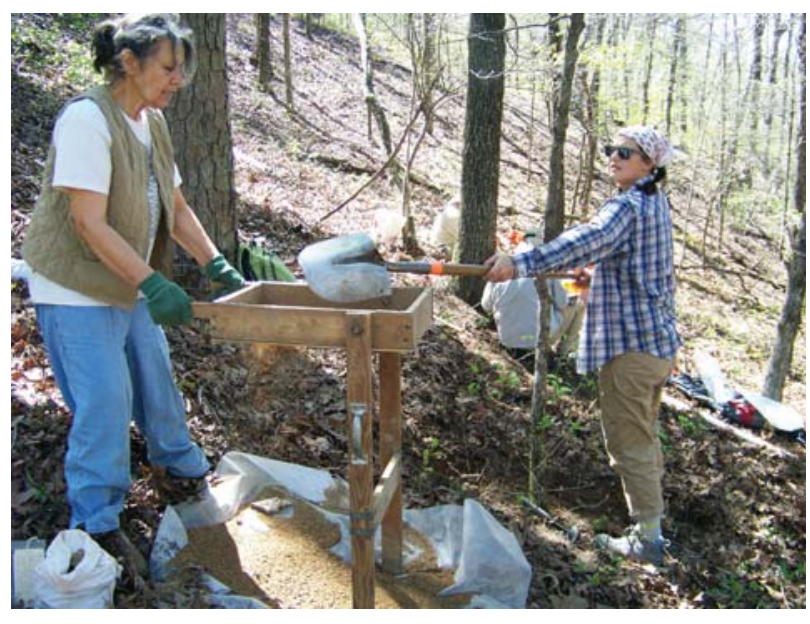

Figure 2. Shovel testing at 3GA22 (Lili Petrovic on left, Katie Leslie on right, Arkansas Archeological Survey).

During weekly

Archeology Lab Days, volunteers have been assisting us with several projects. We have begun a new inventory of the collections curated at ARAS/HSU. The research station has been active since 1967, and we are using our 50th anniversary as an opportunity to digitize paper records and update our electronic databases (the station inventories as well as site forms in AMASDA, the Automated Management of Archeological Site Data in Arkansas, and novaculite distribution data in the "Arkansas Novaculite: A Virtual Comparative Collection" website, http://archeology.uark.edu/ novaculite/index.html). I encourage archeologists working across the Caddo Area to visit that website and add data on novaculite artifacts found at sites beyond the Ouachita Mountains source area. In the future, we hope to create regional distribution maps for different time periods.

We continue to document ceramic vessels in the Joint Educational Consortium's Hodges Collection, curated on the HSU campus (http://archeology.uark. edu/learn-discover/current-research/hodges/). Some of the artifacts in this collection can be tied to known archeological sites, and provide information about Caddo Indian history and lifeways in the Middle Ouachita River valley. We have used objects from this 

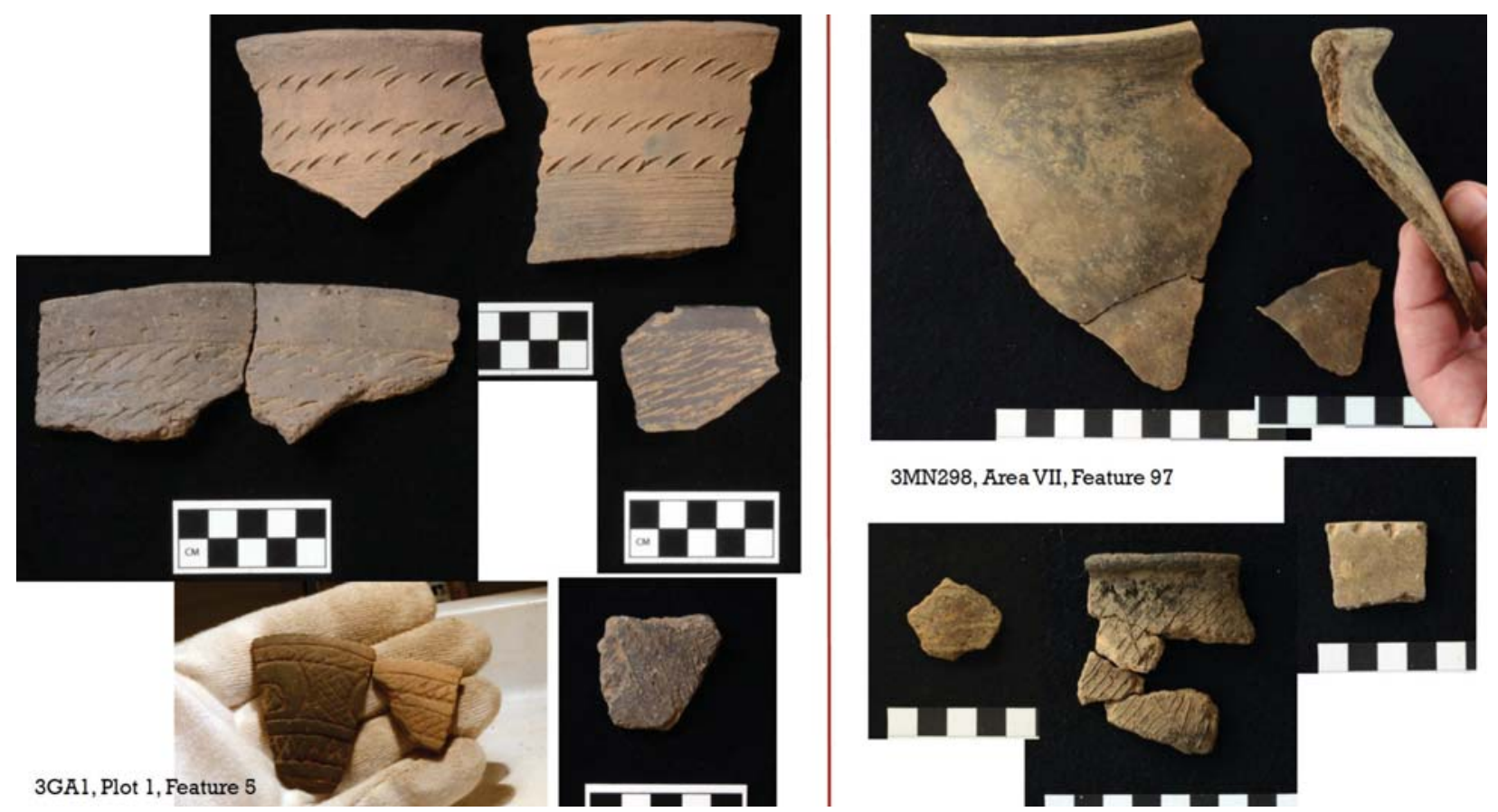

3MN298, Area VII, Feature 97

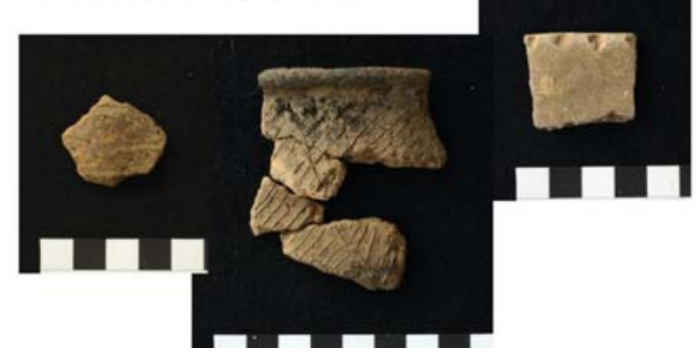

Figure 3. Selected sherds from Adair (3GA1, left) and Dragover (3MN298, right).

collection to develop exhibits that interpret this history for local residents. Our documentation is also used by officials from the JEC and the Caddo Nation as they consult about the collection. At this time, we have completed analysis on about 80 percent of the vessels and are entering the information into a database. One article resulting from this work was published recently (Trubitt and Evans 2015) and another is forthcoming.

Another 2016 field project involved geophysical surveying and test excavations at 3HS151, a site in the Middle Ouachita River valley with damage from recent looting. Jami Lockhart (Arkansas Archeological Survey, Computer Services Program) conducted gradiometry survey across $920 \times 20 \mathrm{~m}$ grids, and Mary Beth Trubitt, Katie Leslie, and several volunteers mapped the site and excavated three test units. Although we did not uncover cultural features, artifacts recovered during testing show that the site has Late Archaic to Fourche Maline and Caddo period components. Katie Leslie presented results of this project at the 2016 Caddo Conference, and a report is in preparation.

We continue to analyze and interpret results from the 2013-2014 excavations at 3MN298, a collaborative project that I directed with Meeks Etchieson (Ouachita National Forest, retired) (http:// archeology.uark.edu/learn-discover/current-research/ ouachita-mountains/). Results of radiocarbon dating and floral and faunal analyses were published in the spring of 2016 (Trubitt and Leslie 2016; Trubitt et al. 2016). To address questions of social identity and regional interaction in and beyond the Ouachita Mountains, we have been analyzing ceramic sherds from the 3MN298 excavations, looking particularly at paste composition, temper recipes, firing conditions, shape or form, and decoration. As we broaden our view from 3MN298, we are also looking at Adair (3GA1), the nearest mound center during the Caddo period. Adair was excavated by University of Arkansas Museum crews in 1939 under the federal Works Projects Administration program. A brief examination of 3GA1 sherds from the University of Arkansas (UA) Museum collections indicates both similarities and differences (Figure 3). We are using instrumental neutron activation analysis (INAA) to analyze trace elements in the ceramic sherd pastes, and establish the chemical signatures of local ceramics. With permission from the Caddo Nation and the UA Museum, and with funding from the U.S. Forest Service and a rate reduction grant from the University of Missouri Research Reactor's Archaeometry Laboratory (MURR), I selected and submitted to MURR a sample of 35 ceramic sherds and two mussel shells from 3MN298 and 3GA1 for INAA. The results will be used in interpretations of communities of pottery-making practice in the Ouachita Mountains. This study will also add to the INAA database of Caddo Area ceramics (see also Trubitt, Perttula, and Selden 2016).

The ARAS/HSU Research Station had some personnel changes in 2016. Katie Leslie left in May for a new position at the Veterans Curation Program in their St. Louis lab. Her replacement should be in Arkansas by the 2017 Caddo Conference. 


\section{References Cited}

Holmes, William Henry

1891 Aboriginal Novaculite Quarries in Garland County, Arkansas. American Anthropologist 4(4):313-316.

1919 Handbook of Aboriginal American Antiquities, Part I, Introductory, The Lithic Industries. Bulletin 60. Bureau of American Ethnology, Smithsonian Institution, Washington, D.C. (Gustav's Library reprint).

Trubitt, Mary Beth

2005 Mapping a Novaculite Quarry in Hot Springs National Park. Caddoan Archeology Journal 14:17-33.

2016 Monitoring and Archeological Documentation at 3GA22, Hot Springs National Park, Garland County, Arkansas. Limited distribution report, Arkansas Archeological Survey, Henderson State University Research Station, Arkadelphia.
Trubitt, Mary Beth, and Linda Evans

2015 Revisiting a Historic Manuscript: Vere Huddleston's Report on East Place (3CL21) Excavations. Caddo Archeology Journal 25:73144.

Trubitt, Mary Beth, and Katie Leslie 2016 2013-2014 Society Training Program Excavations: The Dates. Field Notes: Newsletter of the Arkansas Archeological Society 390:6-14.

Trubitt, Mary Beth, Timothy K. Perttula, and Robert Z. Selden, Jr.

2016 Identifying Ceramic Exchange and Interaction between Cahokia and the Caddo Area. In Research, Preservation, Communication: Honoring Thomas J. Green on His Retirement from the Arkansas Archeological Survey, edited by Mary Beth Trubitt, pp. 87-102. Research Series No. 67, Arkansas Archeological Survey, Fayetteville.

Trubitt, Mary Beth, Leslie L. Bush, Lucretia S. Kelly, and Katie Leslie

2016 Ouachita Mountains Foodways: Preliminary Results from 2013-2014 Excavations at 3MN298. Caddo Archeology Journal 26:50-79. 